\title{
PAYING FOR OUR PERIODS: THE CAMPAIGN TO TACKLE PERIOD POVERTY AND END THE TAMPON TAX IN THE UK
}

\section{LAURA ARGYROPULO CORYTON \& LUCY MARIE RUSSELL*}

Tampon tax and period poverty activist movements are growing in tandem worldwide. ${ }^{1}$ These movements are reshaping the way we think about menstruation and what governments can do to tackle period-based injustices. Through this Essay, two United Kingdom (UK) period activists will explore how these UK movements were erected, how they interact with the global movements, and how Brexit has impacted UK menstruation activism and law-making. Finally, they will look ahead to discuss what they believe the future of period activism might look like.

\section{What is the Tampon Tax?}

In Britain, sexism and inequalities are rife throughout our tax system. While you won't pay tax on some items deemed to be essential, like maintaining private helicopters, ${ }^{2}$ you will pay tax on other items deemed to be luxuries. Until 2021, such luxury items included necessary and basic period products, ${ }^{3}$ which nearly all adolescent girls, women and menstruating adults require on a regular basis for the majority of their lives. Despite being natural and healthy, periods are still hidden and taboo, leaving

\footnotetext{
* Lucy Marie Russell campaigns for girls' rights in the UK and has secured changes in policy around teenage pregnancy, sex and relationships education, street harassment and more. She founded The State of Girls' Rights in the UK report and ran campaigns to end period poverty and taboos, resulting in securing a period blood-drop emoji and her most recent role as Deputy Co-Chair of the UK Government's Period Poverty Task Force. Laura Argyropulo Coryton, starter of the UK end tampon tax petition, which gained 320,000 signatures and changed UK law in March 2020. Laura is also the author of Speak Up! and founded Sex Ed Matters, a social enterprise dedicated to tackling sex and relationship taboos in UK schools. She joined the UK Government's Period Poverty Task Force as a member of their 'stigma' stream in 2019.

${ }^{1}$ See Associated Press, Period Poverty: UK Becomes Latest Country to Abolish Taxes on Women's Sanitary Products, EURONEWS (Jan. 1, 2020), https://www.euronews.com/2021/01/01/period-poverty-uk-becomeslatest-country-to-abolish-taxes-on-women-s-sanitary-products [https://perma.cc/8KF4-99M8].

${ }^{2}$ HM Revenue \& Customs, VAT Rates on Different Goods and Services, GOV.UK (Dec. 31, 2020), https://www.gov.uk/guidance/rates-of-vat-on-different-goods-and-services [https://perma.cc/8ZSR-UZFY].

${ }^{3}$ HM Treasury, Tampon Tax Abolished From Today, GOV.UK (Jan. 1, 2021), https://www.gov.uk/government/news/tampon-tax-abolished-from-today [].
} 
women, girls and others who menstruate paying more for products and silenced about their bodies. In this article, two activists tell the story of how a desire to end sexist policies - and give girls in the UK a voice - led to large scale policy shifts in the UK.

Tampon tax is the "luxury" tax rate that many countries apply to period products worldwide. In the UK, this rate was introduced at $17.5 \%$ in $1973,{ }^{4}$ before it was reduced to $5 \%$ in $2001^{5}$ and abolished entirely in $2021 .^{6}$ Meanwhile, other more menial items have always escaped tax altogether because they have been deemed "essential." Such taxfree items include crocodile meat, ${ }^{7}$ bingo, ${ }^{8}$ and alcoholic dessert jellies. ${ }^{9}$

\section{The Beginnings of the Campaign}

When Laura Coryton read about this sexist legal obscurity for the first time in 2014, she was shocked. Soon after that shock subsided, she became angry. She began to ask herself how the UK government could so gravely misunderstand and side-line the needs of menstruators. What kind of message about women does tampon tax send to society? Does the government not value female participation in the public sphere? How has this clear example of sexism been able to thrive for so many years? Laura wanted to turn her anger and confusion into action. She couldn't find a campaign to support or petition to sign about this online, so she decided to start her own. ${ }^{10}$

Over the following six years, a lot of campaigning took place! Laura campaigned alongside Jennifer Weiss-Wolf, ${ }^{11}$ the superpower behind the United States' sister tampon

\footnotetext{
${ }^{4}$ Antony Seely, VAT on SANitary PRotection 11 (House of Commons Library, Aug. 9, 2021).

${ }^{5} I d$. at 12 .

${ }^{6}$ HM Treasury, supra note 3 .

${ }^{7}$ HM Revenue \& Customs, supra note 2.

${ }^{8}$ HM Revenue \& Customs, Food Products (VAT Notice 701/14), note 3.1, GOV.UK (May 25, 2021), https://www.gov.uk/guidance/food-products-and-vat-notice-70114 [https://perma.cc/7MMR-UKTH].

${ }^{9}$ HM Revenue \& Customs, Food Products (VAT Notice 701/14), note 3.7.1, GOV.UK (May 25, 2021), https://www.gov.uk/guidance/food-products-and-vat-notice-70114 [https://perma.cc/7MMR-UKTH].

${ }^{10}$ Laura Coryton, Stop Taxing Periods. Period. \#EndTamponTax, ChAnge.org (2014), https://change.org/endtampontax [https://perma.cc/86XX-DDQ4].

${ }^{11}$ Jennifer Weiss-Wolf, PERIOD EQUITY, https://www.periodequity.org/founders [https://perma.cc/QE3S$6 \mathrm{~S} 7 \mathrm{G}]$.
} 
tax campaign, and connected with many other activists who were campaigning to end tampon tax all over the world. She also organized demonstrations ${ }^{12}$ and visited schools and universities across the UK to meet the inspiring student activists helping to end tampon tax and widen access to period products at their educational institutions.

\section{Tackling Tax in UK and European Union Law}

In early 2015, Laura began to form a crucial campaign partnership with Paula Sherriff MP, who took her petition to parliament. ${ }^{13}$ Together, they secured their first big campaign win the following November. In his 2015 Autumn statement announcement, then Chancellor of the Exchequer George Osborne MP committed the UK government to ending tampon tax as soon as legally possible. ${ }^{14}$ In the meantime, he launched the 'Tampon Tax Fund', ${ }^{15}$ which would give the fifteen million pounds raised annually from Tampon Tax to "women's health and support charities." these developments seemed at first, they actually marked the beginning of a long legal road to campaign victory.

Both Laura and Paula soon realized that they still had to overcome one last legal hurdle to eliminating tampon tax in the UK. The European Union (EU) is the autonomous body responsible for taxation regulation across all member states. This meant that one of two things had to occur before tampon tax could be axed in the UK or any other EU country: either the EU had to pass legislation that would allow any member state to end tampon tax if it so wished, or the UK had to leave the EU and regain sovereignty over its own taxation laws.

\footnotetext{
${ }^{12}$ See Laura Coryton, David Cameron is Finally Recognising Our Bloody Periods, The TelegraPh (2015), https://www.telegraph.co.uk/women/womens-politics/11957678/Tampon-tax-David-Cameron-is-finallyrecognising-our-bloody-periods.html [https://perma.cc/XZE3-DFPR].

${ }^{13}$ See Paula Sherriff, Parliamentary Questions, Column 102, PARLIAment.uK (Oct. 26, 2015) https://publications.parliament.uk/pa/cm201516/cmhansrd/cm151026/debtext/151026-0003.htm [https://perma.cc/XA9Z-YYB8].

${ }^{14}$ The Rt. Hon. George Osborne, Chancellor of the Exchequer, UK Parliament, Spending Review and Autumn Statement 2015 Speech (Nov. 25, 2015).

${ }^{15} \mathrm{Id}$.

${ }^{16} I d$.
} 
In 2016, both of these prerequisites occurred. The EU began to pass the legislation it needed to allow any member state to end tampon tax if it wished ${ }^{17}$ (due to be complete in 2022), and the UK voted to leave the EU. By 2020, as the Brexit transition period drew to a close and public pressure mounted to end tampon tax-over 318,000 people had signed Laura's petition ${ }^{18}$ - Chancellor of the Exchequer Rishi Sunak MP announced, "I can also confirm that now we have left the EU, I will abolish the tampon tax." ${ }^{19}$

\section{The UK Period Poverty Movement}

In 2017, Tina Leslie, a Leeds based health worker and founder of the charity Freedom4Girls, raised concerns about a new concept ${ }^{20}$ dubbed "period poverty" by the press. ${ }^{21}$ The term period poverty refers to a situation where girls, women and other menstruators do not have enough money to afford basic products to manage their periods; like pads, tampons, and menstrual cups; or can only afford products that do not work well and cause menstrual blood leaks. Research and anecdotal evidence indicate that product quality often impacts the ability to stay clean effectively and should be taken seriously as part of the wider issue of period poverty. ${ }^{22}$ Further research to understand period poverty ${ }^{23}$ found that cost and availability of products, shame, stigma, and a lack of knowledge about reproductive health and products created a "toxic trio" of period

\footnotetext{
${ }^{17}$ Deal Reached to Scrap 'Tampon Tax', Officials Say, BBC News (Mar. 17, 2016), https://www.bbc.com/news/uk-politics-35834142 [https://perma.cc/MFW3-HXQA].

${ }^{18}$ Coryton, supra note 10.

${ }^{19}$ Rishi Sunak, Chancellor of the Exchequer, UK Parliament, Financial Statement (Mar. 11, 2020).

${ }^{20}$ Girls 'Too Poor' to Buy Sanitary Protection Missing School, BBC News (Mar. 14, 2017), https://www.bbc.com/news/uk-39266056 [https://perma.cc/T5WA-J2RX].

${ }^{21}$ Woman's Hour, Why 'Period Poverty' Is a Bigger Problem Than We Think, BBC (Mar. 4, 2017), https://www.bbc.co.uk/sounds/play/p04wxpgr [https://perma.cc/K768-WT6H].

${ }^{22}$ Chloe Tingle \& Shailini Vora, Break the Barriers: Girls' Experiences of Menstruation in the UK 46 (Lucy Russel \& Kerry Smith eds., Jan. 2018).

${ }^{23} \mathrm{Id}$. at 32 .
} 
poverty. ${ }^{24}$ Although this article focuses on the UK, period poverty impacts girls, women, and other menstruators in many countries globally. ${ }^{25}$

Tina Leslie had been looking into the causes of girls' absenteeism from education, and what she discovered were stories of period poverty: of girls using rolled up toilet paper and similar makeshift products to manage their periods because they couldn't afford period products. ${ }^{26}$ They were embarrassed by both their periods and their lack of money. ${ }^{27}$ The taboo and stigma added to the practical challenges of managing a period and led the girls to miss school.

One initial press article became a major story as it became clear that these girls' hidden struggles were not local, but indicative of a national problem. ${ }^{28}$ Stories emerged from across the UK of girls and women who were already struggling with low income or minimal state benefits and could not afford period products. ${ }^{29}$ Many turned to makeshift solutions as a result. ${ }^{30}$ These stories also made clear to us that the Tampon Tax was not just an outdated and sexist policy; it was also contributing to period poverty for the most vulnerable in the UK and worldwide.

\footnotetext{
${ }^{24}$ Lucy Russell, Fighting Period Poverty's Toxic Trio, Plan InT'L UK (Apr. 4, 2018), https://planuk.org/blogs/fighting-period-povertys-toxic-trio [https://perma.cc/TD43-3RHP].

${ }^{25}$ Lucy Russell, Whether Kent or Kampala, Girls Are Struggling with Period Poverty. It's Time for Action, PLAN INT'L UK (Mar. 13, 2019), https://plan-uk.org/blogs/girls-are-struggling-with-period-poverty-its-timefor-action [https://perma.cc/TD43-3RHP].
}

${ }^{26}$ Woman's Hour, supra note 21.

${ }^{27} \mathrm{Id}$.

${ }^{28} I d$.

${ }^{29}$ Schoolgirl Claims Period Poverty Still a 'Serious Issue', BBC News (Mar. 8, 2018), https://www.bbc.com/news/uk-england-leeds-43329406 [https://perma.cc/5N9R-JGA6]; "Plan International UK co-hosted the first ever UK Period Summit addressing shame, stigma, education, health and period poverty in its many different forms. [They] asked attendees to map, wherever possible, their case study evidence of period poverty to create the first ever map of period poverty. [They] heard was a series of stories from across the UK...[they] heard from grassroots individuals who were trying to help family and friends, and from larger organised groups like local political parties, foodbanks and supermarkets, who were collecting sanitary wear for girls and women in their local area." Russell and Smith, supra note 22, at 43.

${ }^{30}$ Simon Murphy, Period Poverty: Wales Schoolgirls to Be Given Free Sanitary Products, THE Guardian (Apr. 13, 2019), https://www.theguardian.com/uk-news/2019/apr/13/period-poverty-wales-schoolgirls-to-begiven-free-sanitary-products [https://perma.cc/D7J7-C3TJ]. 
During this time, Lucy Russell and Kerry Smith were working at Plan International UK and had just launched the 'Because I am a Girl' campaign ${ }^{31}$ for girls in the UK. On seeing the press coverage around period poverty, they felt concerned that girls' voices were missing from the conversation. Together with lead authors Janie Hampton and Mandu Reid, they brought together a network of experts and produced a report on girls' experiences of menstruation in the UK. ${ }^{32}$ It revealed that girls were missing essential education about their bodies and boys were often excluded from the education that was provided, reinforcing the concept that periods were shameful and something to hide. Girls were being humiliated at school for period leaks or having to ask for period products and many struggled to get the products they needed. Girls were often not allowed to go to the toilet during $\operatorname{class}^{33}$ and felt they had to hide their menstruation at all costs.

Survey data found that forty-eight percent of girls in the UK felt embarrassed by their period, ${ }^{34}$ twenty-seven percent of girls in the UK have overused a sanitary product because they couldn't afford a fresh one, ${ }^{35}$ and forty-nine percent of girls in the UK have missed an entire day of school because of their period. ${ }^{36}$ This research helped activists push forward a period agenda. It legitimized their calls to tackle period stigma and poverty by changing laws and implementing policies.

\footnotetext{
${ }^{31}$ Because I Am a Girl, PLAN INT'L UK, https://plan-uk.org/act-for-girls [https://perma.cc/86H5-Q37Q].

${ }^{32}$ Russell and Smith, supra note 22.

${ }^{33}$ Locked Out: It's Time to Stop Locking Girls Out of School Toilets When They Have Their Period, PLAN INT'L UK, https://plan-uk.org/girls-rights-in-the-uk/break-the-barriers-our-menstrual-manifesto/locked-out [https://perma.cc/4GNS-GP3Y].
}

${ }^{34}$ Almost Half of Girls Aged 14-21 Are Embarrassed by Their Periods, Plan InT'L UK (Oct. 9, 2017), https://plan-uk.org/media-centre/almost-half-of-girls-aged-14-21-are-embarrassed-by-theirperiods\#: :text=Nearly\%20half\%20(48\%20per\%20cent,teenage $\% 20$ girls $\% 20$ in $\% 20$ the $\% 20$ UK [https://perma.cc/PA2S-LD7V].

${ }^{35}$ Forty-Percent of Girls Have Used Toilet Roll Because They've Struggled to Afford Sanitary Wear, Survey Reveals, PLAN INT'L UK (Mar. 12, 2018), https://plan-uk.org/media-centre/40-of-girls-have-used-toilet-rollbecause-theyve-struggled-to-afford-sanitary-wear [https://perma.cc/CPF6-AFF2].

${ }^{36}$ Almost Half of Girls Aged 14-21 Are Embarrassed by Their Periods, supra note 34. 


\section{The UK Movement for Menstrual Equity}

In the UK, activists had begun to identify "period poverty" as one of many issues that needed to be addressed if they hoped to achieve menstrual equity. The term menstrual equity was first created by Jennifer Weiss-Wolf ${ }^{37}$ in 2016 where she described:

In order to have a fully equitable and participatory society, we must have laws and policies that ensure menstrual products are safe and affordable and available for those who need them. The ability to access these items affects a person's freedom to work and study, to be healthy, and to participate in daily life with basic dignity. And if access is compromised, whether by poverty or stigma or lack of education and resources, it is in all of our interests to ensure those needs are met. ${ }^{38}$

Activists addressed a wide range of menstruation-related topics, from tackling taboos with comedy ${ }^{39}$ and art $^{40}$ to offering reproductive health information in schools. Many focused on schools, either by providing period products directly ${ }^{41}$ or by calling on the government to provide them. Driven by campaigner Amika George, founder of Free Periods, ${ }^{42}$ a movement grew to call on the government to provide period products in schools. Participants ranged from sexual health organizations to specialist groups-for example, those promoting menstrual cups ${ }^{43}$ or environmentally friendly products, ${ }^{44}$ and

\footnotetext{
37 See Jennifer Weiss-Wolf, Periods Gone Public: Taking a Stand for Menstrual Equity (Arcade 2017).

${ }^{38} I d$. at p. XVI.

${ }^{39}$ See About Chella Quint, PERIOD Positive, https://periodpositive.com/about/about-chella-quint/ [https://perma.cc/VV56-7YVC].

${ }^{40}$ See NATALIE ByRnE, https://nataliebyrne.uk/ [https://perma.cc/L2U5-RWSD].

${ }^{41}$ See Schools, THE RED Box PROJECT, http://redboxproject.org/schools/ [https://perma.cc/2DHE-GN7W].

${ }^{42}$ FREE PERIODS, https://www.freeperiods.org/ [https://perma.cc/HBG9-UUJ3].

${ }^{43}$ See The CuP EFFECT, https://www.thecupeffect.org/ [https://perma.cc/3W4Z-4TS6].

${ }^{44}$ See ELLA DAISH, https://elladaish.com/index.html [https://perma.cc/22WN-F2JX].
} 
those working with the Sikh community ${ }^{45}$ or for trans rights ${ }^{46}$ - global information ${ }^{47}$ and research ${ }^{48}$ hubs, and members of parliament (MPs) ${ }^{49}$ and the House of Lords ${ }^{50}$ One MP broke a centuries old taboo by announcing that she was menstruating in the House of Commons. ${ }^{51}$ Activists also shed light on access to toilets in schools, ${ }^{52}$ free access to a range of products ${ }^{53}$ like menstrual cups ${ }^{54}$ and period pants,${ }^{55}$ and how to ensure those who

\footnotetext{
${ }^{45}$ See BINTI., https://bintiperiod.org/ [https://perma.cc/D69F-LCGN].

${ }^{46}$ See Kenny Jones, Getting My Period Made Me Feel Like Less of a Man - Even Though I Knew I Was, SELF (May 24, 2018), https://www.self.com/story/male-period-trans-model-kenny-jones [https://perma.cc/SM87-S74U].
}

${ }^{47}$ See What Is the Menstrual Health Hub?, The Menstrual Health Hub, https://mhhub.org/about/ [https://perma.cc/DK4V-8WKR].

${ }^{48}$ See About, MenSTRUAL MATTERs (Nov. 5, 2016), https://www.menstrual-matters.com/about/ [https://perma.cc/7SQ7-XVL6].

${ }^{49}$ Wendy Chamberlain MP, We Must End Period Poverty Globally, PoliticsHome (Mar. 4, 2020), https://www.politicshome.com/thehouse/article/we-must-end-period-poverty-globally

[https://perma.cc/W37F-5MP2].

${ }^{50}$ See Laura Coryton, The Lords and Commons Are Discussing Period Poverty - That's Pretty Amazing, HufFingTON POST (Mar. 24, 2018), https://www.huffingtonpost.co.uk/laura-coryton/the-lords-and-commonsare_b_15569270.html [https://perma.cc/6XNJ-ATK4].

${ }^{51}$ Sarah Marsh, MP Breaks House of Commons Taboo by Discussing Her Period, The Guardian (June 28, 2018), theguardian.com/politics/2018/jun/28/danielle-rowley-breaks-house-of-commons-taboo-discussingperiod [https://perma.cc/6J9A-H3ZB].

${ }^{52}$ See Locked Out: It's Time to Stop Locking Girls Out of School Toilets When They Have Their Period, supra note 33.

${ }^{53}$ See Dr. Annalise Weckesser et. al., Best Practice and Innovations in UK Period Poverty Initiatives, PLAN IN'TL UK, https://plan-uk.org/file/plan-uk-ltp-learning-briefing-2pdf/download?token=XbJhBfCy [https://perma.cc/6VLC-JXEW].

${ }^{54}$ See Welcome, Menstrual CuP COALITION, https://menstrualcupcoalition.org/ [https://perma.cc/4RTQ2L5B].

${ }^{55}$ See WuKA, https://wuka.co.uk/ [https://perma.cc/9PKP-BL36]. 
need the products the most, for example refugees and asylum seekers ${ }^{56}$ or homeless women, ${ }^{57}$ are not left behind.

The menstrual equity movement didn't end there. Trade unions began to ask what needed to be addressed at work. Academia increasingly recognized menstrual equity as an academic topic. And activists who had been suffering in silence calling for recognition of endometriosis, ${ }^{58}$ gynecological cancer, ${ }^{59}$ premenstrual dysphoric disorder, ${ }^{60}$ and menopausal effects found their voices joined and bolstered by the calls for change.

\section{The Global Movement to Tackle 'Tampon Tax'}

Tampon tax campaigns have had varied success across the world, painting an interesting global picture of sexism. For example, the French government claimed they made too much money from tampon tax to justify its abolition and continue to capitalize from this clear symptom of sexism to this day, albeit at a reduced rate of 5.5 per cent. ${ }^{61}$ On the other hand, during his presidency, Barak Obama not only opposed tampon tax but also claimed that if a greater proportion of politicians were women, we wouldn't even be debating this topic as the tax simply wouldn't exist. ${ }^{62}$ Yet, some states, including Texas, continue to tax period products while granting tax exemption to other items on the grounds of essentiality, including cowboy boots. In a similar acknowledgement of

\footnotetext{
56 “A Pad for Me, or a Nappy for My Baby?”, Bloody Good PerIod (2019), https://www.bloodygoodperiod.com/period-poverty [https://perma.cc/UZ74-J4B6].

${ }^{57}$ Shailini Vora No More Taboo: Tackling Period Poverty (2017), https://irpcdn.multiscreensite.com/0659695e/files/uploaded/TPP-Report.pdf [https://perma.cc/R285-7VY9].

${ }^{58}$ See ENDOMETRIOSIS UK, https://www.endometriosis-uk.org/teach-periods [https://perma.cc/9QVV-M63K].

${ }^{59}$ See THE EvE APPEAL, https://eveappeal.org.uk/getting-involved/take-part-in-an-event/gcam/ [https://perma.cc/VBM5-7FW7].

${ }^{60}$ See Vicious Cycle PMDD, https://www.viciouscyclepmdd.com/aims-objectives [https://perma.cc/D2WKD89C].

${ }^{61}$ France Rejects 'Tampon Tax' Change, BBC NEws (Oct. 15, 2015), https://www.bbc.com/news/worldeurope-34538672 [https://perma.cc/7V74-65NB].

${ }^{62}$ Maya Rhodan, President Obama Doesn't Understand the 'Tampon Tax' Either, TIME (Jan. 15, 2016), https://time.com/4183108/obama-tampon-tax-sanitary/ [https://perma.cc/YE5E-H8VS].
} 
sexism, India axed its tampon tax in $2018^{63,64}$ in part thanks to charities such as Binti, ${ }^{65}$ which helped to open conversations about menstruation and in doing so, took a significant step to challenge the period taboo.

Furthermore, Rwanda, ${ }^{66}$ Nigeria,${ }^{67}$ and South Africa ${ }^{68}$ have reduced taxes on period products over the last few years, and big funders and UN-level organizations are paying attention. ${ }^{69}$ In Ethiopia, the tax on period products had been high ${ }^{70}$, leading to a situation where women and girls could not afford adequate period products and instead were using cow dung bricks, normally a good source of fuel, instead of menstrual pads. ${ }^{71}$ A serious consequence has been that girls are missing days of school, sometimes dropping out

${ }^{63}$ India Ditches 'Tampon Tax' After Protests, Fin. Times (July 22, 2018), https://www.ft.com/content/5cc3e2a4-8d6d-11e8-b639-7680cedcc421 [https://perma.cc/7AGU-XFYZ].

${ }^{64}$ India Scraps Tampon Tax After Campaign, BBC News (July 21,2018), https://www.bbc.com/news/worldasia-india-44912742 [https://perma.cc/P6T5-9JE4].

${ }^{65}$ BINTI INTERNATIONAL, https://bintiperiod.org/ [https://perma.cc/D69F-LCGN].

${ }^{66}$ Rwanda Removes VAT on Sanitary Products, as the Fight to End Period Poverty Continues, The London SCH. Of ECON. AND Pol. SCI. (Jan. 17, 2020),

https://blogs.lse.ac.uk/internationaldevelopment/2020/01/17/rwanda-removes-vat-on-sanitary-products-asthe-fight-to-end-period-poverty-continues/ [https://perma.cc/B5F7-ZZNU].

${ }^{67}$ Anamelechi Chidinma, Pink Tax and the Fight Against Tampon Tax in Nigeria, UTOPIA EDUCATORS (Nov. 6, 2020), https://utopiaeducators.com/posts/nigerian-pink-tax/ [https://perma.cc/6AMK-A4WM].

${ }^{68}$ Leah Rodriguez, Menstrual Products Have Been Declared Tax Free in South Africa, Global Citizen (Oct. 24, 2018), https://www.globalcitizen.org/en/content/south-africa-sanitary-pads-tax-lifted/ [https://perma.cc/YK2Q-NZUP].

${ }^{69}$ A good example of this is to compare the World Health Org., Global Strategy for WOMEN's, CHILDREN's AND AdOLESCENTS' HEALTH 2016-2030, https://www.who.int/data/maternal-newbornchild-adolescent-ageing/global-strategy-data [https://perma.cc/RRZ9-NVVB] which does not mention menstruation with the new UNFPA, TECHNICAL BRIEF ON THE INTEGRATION OF MENSTRUAL Health inTo Sexual and Reproductive Health and Rights Policies and Programmes (May 2021), https:/esaro.unfpa.org/en/publications/technical-brief-integration-menstrual-health-sexual-and-reproductivehealth-and-right-0 [https://perma.cc/XN99-2UZG].

${ }^{70}$ Bryn Welham, Taxes and Duties for Sanitary Products in Africa, UK Aid \& Work and OPPORTUNITIES FOR WOMEN (May 2020), https://assets.publishing.service.gov.uk/government/uploads/system/uploads/attachment_data/file/891903/Qu ery-50-Ethiopia-taxation-sanitary-products.pdf [https://perma.cc/6HEP-2FPC].

${ }^{71}$ JegnitEthiopia (@jegnit), TwitTER (Dec.29, 2020), https://twitter.com/jegnit/status/1344067727523246084?s=20 [https://perma.cc/T2NC-ZNJR]. 
completely, because they can't afford period products. Women's rights activist organization Jegnit Ethiopia ${ }^{72}$ organized the \#Stop_taxing_my_period campaign about the tax, often drawing aspects from the UK campaigns and using Ethiopian celebrities and mass social media pressure. Yet taxes on period products are still a problem for many, and calls for change are still active in places including Ghana, ${ }^{73} \mathrm{China}^{74}$ and many states across the U.S. ${ }^{75}$

\section{The Global Movement for Menstrual Equity}

The movement to focus on menstruation-whether it emphasizes the cost of products, impact on school attendance, taboos and shame, or physiological knowledgehas taken the world by storm. To put this UK movement into perspective, as Dr. Venkatraman Chandra-Mouli recently noted, ${ }^{76}$ menstrual equity wasn't a Sustainable Development Goal or on UN-level radars when governing bodies set human development goals for the next ten years. Rather, the movement came from the global south and is a great example of the power of women and girls to make change. Indian activists led the way with marches and activism. ${ }^{77}$ The story of a man who designed much-needed period

\footnotetext{
72 JEGNIT ETHIOPIA, https://jegnitethiopia.com/ [https://perma.cc/35QA-92N4]; Jegnit, FACEBOOK WATCH (Dec. 29, 2020, 4:17 PM), https://fb.watch/v/a2IWv-Oh2/ [https://perma.cc/PPD6-T2CL]; Jegnit, FACEBOOK (Dec. 28, 2020), https://www.facebook.com/297672027506675/posts/745340559406484/?d=n [https://perma.cc/4KRD-F5VZ]; Jegnit, FACEBOOK (Dec. 28, 2020), https://www.facebook.com/297672027506675/posts/745324486074758/?d=n [https://perma.cc/7NE9-3F8U].
}

${ }^{3}$ Sonia Narang, 7 Activists in 7 Countries Who Want to Strip Menstruation of Stigma, THE LiLy (Dec. 14, 2018), https:/www.thelily.com/7-activists-in-7-countries-who-want-to-strip-menstruation-of-stigma/? [https://perma.cc/BX2L-TAUY].

${ }^{74}$ Jingyan Zhang, Period Poverty in China and Current Campaigns, The Borgen Project (Dec. 15, 2020), https://borgenproject.org/period-poverty-inchina/\#: :text=As $\% 20$ of $\% 202020 \% 2 \mathrm{C} \% 20$ the $\% 20$ Chinese,the $\% 20$ tax $\% 20$ on $\% 20$ sanitary $\% 20$ products [https://perma.cc/DX5H-SVMJ].

${ }^{75}$ Karen Zraick, 22 States Considered Eliminating the Tampon Tax This Year. Here's What Happened., N.Y. TiMES (July 12, 2019), https://www.nytimes.com/2019/07/12/us/tampon-tax.html [https://perma.cc/22HZ8EPV].

${ }^{76}$ Dr. Venkatraman Chandra-Mouli, Adolescents and at-Risk Populations Team, Department of Reproductive Health And Research, WHO, (Sept. 12, 2020) speaking at 'Now More Than EVER, ACCElerating Progress on Adolescent SRHR ONE YEAR on From ICPD+25’ Report Launch, Plan InT'L UK.

${ }^{77}$ You can read more about some of the period taboos in India here: Reuters in Delhi, Indian Temples Cannot Bar Women, Rules Supreme Court, The GuARDiAn (Apr. 12, 2016), 
pads got turned into a star-studded Bollywood film - an enormous breakthrough for what had previously been seen as an unacceptable topic. In 2018, the short film documentary 'Period. End of Sentence.,' directed by Rayka Zehtabchi, told the story of a woman breaking taboos. ${ }^{78}$ It was inspired by the life of Arunachalam Muruganantham, a social activist from Tamil Nadu, India, and won an Academy Award, putting the struggle for affordable products and ending taboos at the heart of the arts world.

UN-level bodies like the World Health Organization, ${ }^{79}$ UNFPA, $^{80}$ and UN Women ${ }^{81}$ joined the calls for change, and businesses joined the movement as well. Libresse created a singing Viva la Vulva film ${ }^{82}$ and changed its practice in advertising so that it highlighted taboos around menstruation, including men buying period products, discussing period products, sex during a period and the banning of period blood in

\begin{abstract}
https://www.theguardian.com/world/2016/apr/12/indian-temples-cannot-bar-women-rules-supreme-court [https://perma.cc/SYB8-78YX ]; and about activism to end the 'Tax on Blood' here: Vidhi Doshi, Campaigners Refuse to Throw in the Towel Over India's Tax on Blood, THE GUARDIAN (Apr. 21, 2017), https://www.theguardian.com/global-development/2017/apr/21/campaigners-refuse-to-throw-in-the-towelover-indias-tax-on-blood [https://perma.cc/DZD5-C792]; and about the results of that campaign here: Maya Oppenheim, India Scraps 12\% Tax on Sanitary Pads After Protests, InDEPENDENT (July 26, 2018), https://www.independent.co.uk/news/world/asia/india-sanitary-pads-12-tax-protests-period-poverty-piyushgoyal-a8459801.html [https://perma.cc/Q5DA-GVBY ].
\end{abstract}

${ }^{78}$ Garima Satija, Oscars 2019: India-Based 'Period. End of Sentence' Wins Best Documentary Short Award, INDIA Times (Feb. 25, 2019), https://www.indiatimes.com/entertainment/oscars-2019-india-based-periodend-of-sentence-wins-best-documentary-short-award-362739.html [https://perma.cc/M7MD-EUN5 ]; Period. End of Sentence., NETFLIX (2018), https://www.netflix.com/pt-en/title/81074663 [https://perma.cc/J4ZSYBUX].

${ }^{79}$ Tackling the Taboo of Menstrual Hygiene in the European Region, World HeAlth Org. (Nov. 8, 2018), https://www.euro.who.int/en/health-topics/environment-and-health/water-andsanitation/news/news/2018/11/tackling-the-taboo-of-menstrual-hygiene-in-the-european-region [https://perma.cc/W2LB-HT2W].

${ }^{80}$ Menstruation and Human Rights - Frequently Asked Questions, United NATIONS Population Fund (June 2021), https://www.unfpa.org/menstruationfaq [https://perma.cc/M4NB-ZHBF].

${ }^{81}$ Infographic: End the Stigma. Period., UN Women (Oct. 6, 2019), https://www.unwomen.org/en/digitallibrary/multimedia/2019/10/infographic-periods [https://perma.cc/4TCH-433C].

${ }^{82}$ Libresse 'Viva La Vulva' Advert 2018, YouTuBe (Nov. 27 2018),

https://www.youtube.com/watch?v=lvFF1s5z2RY\&feature=youtu.be\&ab_channel=MachineShopSFX

[https://perma.cc/B4XA-JN2E]. 
advertising, and their subsequent use of red liquid in their advertisements. ${ }^{83}$ One of their follow up advertisements explains how they and their advertising agency took the taboo around period and used it to shape an attitude changing campaign:

Introducing 'Blood Normal,' a campaign that some hated. But that's no surprise. We live in a world that hides periods and shames women for having them. But the way to end period taboo is to normalize it. Normal period blood, in a normal pad demonstration, normal period pain, period sex. Men buying pads, and women asking for them, normally...Blood Normal is helping create a new normal for billions of women and girls. ${ }^{84}$

It wasn't all good news through, sadly, and suffering due to that toxic trio of taboo combined with lack of products and education continues. The world was shocked after a Nepali mother and her two children were found dead after the woman was banished to a "menstruation hut." 85 The tradition, known as chhaupadi, treats periods as polluting. It has been banned in Nepal since 2005 but continues in some rural areas. ${ }^{86}$ Globally, periods are still a leading reason why large numbers of girls are forced to drop out of school, and the availability of products and comprehensive sexuality education about girls' bodies is still far from realized for many young people. ${ }^{87}$

Yet things are changing. BodyForm's advertisement "Womb stories" is groundbreaking in addressing menstrual bleeding, pain, sexual pleasure, contraception,

\footnotetext{
${ }^{83}$ Blood Normal, YouTuBe (Oct. 17, 2017),

https://www.youtube.com/watch?v=wC63ksuupmI\&feature=youtu.be\&ab_channel=LibresseNL [https://perma.cc/5AWZ-PN7Z].

84 'Bloodnormal' by AMV BBDO for Essity, YouTuBE (June 22, 2018), https://www.youtube.com/watch?v=xr57T11Yw2s [https://perma.cc/3PUJ-BET2].

${ }^{85}$ Nepal Woman and Children Die in Banned 'Menstruation Hut', BBC News (Jan. 10, 2019), https://www.bbc.com/news/world-asia-46823289 [https://perma.cc/2DQU-C5G8]

${ }^{86}$ Nepal Criminalises Banishing Menstruating Women to Huts, BBC News (Aug. 10, 2017), https://www.bbc.com/news/world-asia-40885748 [https://perma.cc/772L-WZP2].

${ }^{87}$ Phineas Rueckert, Why Periods Are Keeping Girls Out of School and How You Can Help, Global Citizen (May 30, 2018), https://www.globalcitizen.org/en/content/menstrual-hygiene-day-education/ [https://perma.cc/F4TK-RTQ9].
} 
miscarriage, birth, infertility, and menopause. ${ }^{88}$ It could also be argued that the radical approach to menstruation in the corporate world ${ }^{89}$ came about due to the seeds sown by the global menstrual equity movements.

\section{With COVID-19, Brexit and Increasing Poverty, What's Next for Periods?}

The COVID-19 pandemic has impacted tampon tax and period poverty in the UK in many ways. Poverty in general has increased, ${ }^{90}$ while access to essential products has decreased across the board. ${ }^{91}$ The UK Period Poverty Task Force has ceased business for the foreseeable future, and many schools have not taken up the government's new Free Period scheme, which offers free period products to all primary and secondary students (explained below), as they have had to close. ${ }^{92}$

It's not all bad news, however. Some developments have been incredibly positive. For example, the UK government introduced its first free period scheme on January 20, 2020, which ensures free period products are provided to all schools and colleges across

\footnotetext{
${ }^{88}$ Bodyform \#Wombstories, YouTuBe (July 1, 2020), https://www.youtube.com/watch?v=JZoFqIxlbk0\&feature=youtu.be\&ab_channel=BodyformUK [https://perma.cc/9PY8-LQ7N].

${ }^{89}$ The radical approach amongst corporates was noted for example when Members of The Marketing Society voted Bodyform as its Brave Brand of the Year. "Bodyform's 2017 campaign, "Blood normal", created by Abbott Mead Vickers BBDO, broke new ground in advertising by being the first campaign to depict real menstrual blood, rather than the blue liquid generally shown in feminine-care ads". Simon Gwynn, Bodyform Scoops Brave Brand of the Year Award, CAMPAIGN (Nov. 15, 2018) https://www.campaignlive.co.uk/article/bodyform-scoops-brave-brand-year-award/1499072 [https://perma.cc/U35M-VY8E].

${ }^{90}$ Covid-19 to Add As Many As 150 Million Extreme Poor by 2021, THe World BAnK (Oct. 7, 2020), https://www.worldbank.org/en/news/press-release/2020/10/07/covid-19-to-add-as-many-as-150-millionextreme-poor-by-2021 [https://perma.cc/AY87-ZMFA].

${ }^{91}$ Periods in the Pandemic: 9 Things We Need to Know, UNICEF \& UNFPA (Aug. 31, 2020), https://www.unicef.org/coronavirus/covid-19-periods-in-pandemic-9-things-to-know [https://perma.cc/MKF3-QJDK].

${ }^{92}$ Period Products Scheme, Management Information, DeP’T FOR EDUC. (Jan. 2021), https://assets.publishing.service.gov.uk/government/uploads/system/uploads/attachment data/file/953976/Per iod_Products_Scheme_January_2021.pdf [https://perma.cc/EL4J-BXNG].
} 
England. ${ }^{93}$ The bill was designed to end period poverty in schools and to stop period poverty from interrupting students' education. This scheme was renewed in January $2021 .{ }^{94}$

On November 24, 2020, Scotland passed an unprecedented piece of legislation called the Period Products (Free Provision) (Scotland) Bill..$^{95}$ This Bill, proposed by Monica Lennon MSP, ensures that anyone who needs period products has access to them for free. Importantly, this Bill widened the global conversation around menstruation. It was the first piece of law in the world to treat period poverty and stigma as the universal problem that it is and to support the vast array of people impacted by these issues.

The UK also finally eliminated tampon tax in January $2021 .{ }^{96}$ This change is important for three central reasons. Firstly, it will help the rising number of people in poverty to afford and access period products. Secondly, it sends a strong message to society about menstruators: period products are important to society and so are those who use them. Finally, this policy change challenges period stigma in a powerful way. If the Prime Minister can openly talk about menstruation in the Palace of Westminster, then so can anyone else, anywhere else. Campaigners are now lobbying the UK government to keep the tampon tax fund ${ }^{97}$ which provides female-focused charities with fifteen million pounds annually in the form of back-paid taxes.

The future is bright for period activism. Many effective and previously unimaginable policies have been introduced over the past few years alone, reflecting the power of period activism. In terms of tampon tax, we can expect the European Union to pass a law

\footnotetext{
${ }^{93}$ Free Period Products for All Schools and Colleges, GOV.UK (Jan. 18, 2020), https://www.gov.uk/government/news/free-period-products-for-all-schools-and-colleges [https://perma.cc/SYA4-HPSN].

${ }^{94}$ Department for Education, Period Product Scheme for Schools and Colleges in England, GOV.UK (Dec. 16, 2020), https://www.gov.uk/government/publications/period-products-in-schools-and-colleges/periodproduct-scheme-for-schools-and-colleges-in-england [https://perma.cc/TX2G-YZG3].

${ }^{95}$ Period Products (Free Provision) (Scotland) Bill, The ScotTiSh PARLiament (2021), https://www.parliament.scot/bills-and-laws/bills/period-products-free-provision-scotland-bill [https://perma.cc/YJ9C-2RP9].

${ }^{96}$ Tampon Tax Abolished From Today, supra note 3.

${ }^{97}$ Laura Coryton, Keep the Tampon Tax Fund!, CHANGE.ORG (2020), https://www.change.org/p/rishi-sunakmp-keep-the-tampon-tax-fund [https://perma.cc/ZJ28-75HX].
} 
in 2022 that will allow any member state to axe tampon tax if it so wishes. ${ }^{98}$ We hope this will encourage many EU countries to drop the tax and, with it, a form of period stigma. In the UK, there is still much to do. Period products like reusable pants are still taxed at twenty percent, ${ }^{99}$ and a campaign launched by brand WUKA in January 2021 aims to change that. ${ }^{100}$

\section{After Period Poverty: Education, Workplaces, Decolonization and Getting Talking About Periods}

So, what exactly does the future look like for periods in the UK? Well, for a start, we hope that period products will soon be free everywhere. Gabby Edlin, founder and CEO of charity 'Bloody Good Period', ${ }^{101}$ has started a petition, "Everyone deserves a bloody good period," calling on Westminster to adopt Scotland's bold free period policy. ${ }^{102}$ She wants the government to provide these vital products for free across all nations of the UK. Bloody Good Period also maps out some of the other aspects of menstruation in the UK that need to be addressed. The organization's "Decolonising Menstruation" work aims to end period shame, specifically within the unique experiences of menstruation for black, indigenous and other people of color and for asylum seekers and refugees. ${ }^{103}$ Its education program provides accurate information about menstruators' bodies and works to examine how attitudes to menstruation may have been shaped by "a white male gaze"

\footnotetext{
${ }^{98}$ James Crisp, EU Rules Forcing Britain to Keep Tampon Tax Will Apply for Years After Brexit, THE TELEGRAPH (Jan. 18, 2018), https:/www.telegraph.co.uk/politics/2018/01/18/eu-rules-forcing-britain-keeptampon-tax-will-apply-years-brexit/ [https://perma.cc/S9M6-BXJM].

${ }^{99}$ Early Day Motions: VAT on Period Pants, UK Parliament (Oct. 8, 2020), https://edm.parliament.uk/early-day-motion/57544/vat-on-period-pants [https://perma.cc/TY9U-WRKD].

${ }^{100}$ Period Pants Tax Campaign, WuKa (2021), https://wuka.co.uk/pages/period-pants-tax [https://perma.cc/T6YH-MN5L].

${ }^{101}$ BLOOdY GOOD PERIOD, https://www.bloodygoodperiod.com/ [https://perma.cc/E2MM-W2WF].

102 Gabby Edlin, Provide Free Period Products Across the UK, CHANGE.ORG (2020), https://www.change.org/p/uk-government-provide-free-period-products-across-the-uk [https://perma.cc/L49A-K7ZS].

103 Decolonising Menstruation: An Introduction, BLOODy GOOD PERIOD, https://www.bloodygoodperiod.com/post/decolonising-menstruation-an-introduction [https://perma.cc/E4P6Q767 ]; and Bloody Good Education, BLOODY GoOD PERIOD, https://www.bloodygoodperiod.com/education [https://perma.cc/G9UN-KNS2].
} 
or "othering" that often vilifies and distorts traditional practices. ${ }^{104}$ In addition, Bloody Good Period's Employers Program helps employers improve the support they offer to employees who menstruate. Through all this work, Bloody Good Period seeks to "normalise menstruation" using social media, conversation, art, and more to "eradicate the shame and stigma surrounding menstruation, simply by encouraging the conversation around periods." ${ }^{05}$ In a positive step towards this, Surrey County Council has partnered with Binti International to become the first County Council to offer free period products to anyone who needs them. ${ }^{106}$

Finally, the UK has introduced a fantastic new Relationships and Sex Education (RSE) curriculum for the 2020-2021 academic year. ${ }^{107}$ Many campaigners believe this new curriculum has the power to eradicate period stigma in schools. It covers a range of powerful subjects, such as consent and equality laws, menopause and menstruation, and challenges not only the assumptions that students hold about these topics, but those held by teachers and parents, too. We have seen a rising number of organizations dedicate themselves to supporting this curriculum, including Sex Ed Matters, ${ }^{108}$ which provides campaigning-focused sex ed resources and talks to all schools across the UK.

Many significant policy changes have come into effect over the past few years alone, and countless inspiring campaigns have since sprung up regarding menstruation. These campaigns are spearheaded by fearless girls and women, and politicians are starting to listen. Although the fight to end period stigma is far from over, the future is undoubtedly bright for period equality in the UK.

${ }^{104} I d$.

${ }^{105}$ Normalise Periods: We Need to Bloody Talk About Menstruation, Bloody Good Period, https://www.bloodygoodperiod.com/normaliseperiods [https://perma.cc/LY4L-5WPH].

${ }^{106}$ Period Stigma: Surrey County Council to Provide Free Period Products, BBC News (May 25, 2021), https://www.bbc.co.uk/news/uk-england-surrey-

57243293\#: :text=Period\%20stigma\%3A\%20Surrey\%20County\%20Council\%20to\%20provide $\% 20$ free $\% 20$ period\%20products,-

25\%20May\&text=Organisations\%20are\%20being\%20encouraged $\% 20$ to,stigma $\% 20$ it $\% 20$ says $\% 20$ still\%20e xists [https://perma.cc/48QL-JYM5].

${ }^{107}$ Department for Education, Relationships and Sex Education (RSE) and Health Education, GOV.UK (Sept. 12, 2021), https://www.gov.uk/government/publications/relationships-education-relationships-and-sexeducation-rse-and-health-education [https://perma.cc/7N3Q-ZCM6].

${ }^{108}$ SeX ED MATTERS, https://www.sexedmatters.co.uk/ [https://perma.cc/AS96-GJZR]. 